\title{
STATUS TERUMBU KARANG DAN IKAN KARANG DI PERAIRAN SIDODADI DAN PULAU TEGAL PROVINSI LAMPUNG
}

\author{
Syahnul Sardi Titaheluw* \\ Staf Pengajar FAPERTA UMMU-Ternate, Email: titaheluw@outlook.com
}

\begin{abstract}
ABSTRAK
Penelitian ini bertujuan untuk melihat status terumbu karang dan ikan karang di periaran sidodadi dan tegal provinsi lampung. Penelitian ini dilaksanakan pada bulan mei sampai juli tahun 2010 di 6 stasiun. Pengumpulan data dilakukan dengan menggunakan metoda sensus visual dan line intersep transek (transek garis). Jumlah ikan yang ditemukan sebanyak 684 ekor yang mewakili 14 suku, yaitu; Pomacentridae (10 jenis), Pomachantidae (3 jenis), Caesio (1 jenis), Scaridae (3 jenis), Labridae (8 jenis), Apongidae (6 jenis), Chaetodontidae (3 jenis), Chelmon (1 jenis), Serranidae (2 jenis), Siganidae (2 jenis), Lutjanidae (1 jenis) Acanhuridae (5 jenis) dan Haemulidae (2 jenis). Naik turunnya indeks keanekaragaman, keragaman dan dominansi dapat menjadi indikator kualitas terumbu karang dan famili Chaetodontidae paling baik digunakan sebagai idikator. Keanekaragaman $\left(H^{\prime}\right)$ berkisar antara 0.28-1.38 dan persentase tutupan karang hidup antara 47,94\% sampai $67,14 \%$. Status terumbu karang secara umum dalam kondisi baik, namun kegiatan antropogeik pada beberapa lokasi akan mempercepat degradasi terumbu karang, terutama tanpa adanya pengawasan. Rusaknya kondisi lingkungan tersebut menyebabkan persentase atau kehadiran ikan-ikan karang yang ditemukan di lokasi penelitian lebih sedikit dibandingkan dengan lokasi-lokasi lainnya di Indonesia.
\end{abstract}

Kata Kunci : Sidodadi, Tegal, Terumbu Karang, Ikan Karang..

\section{PENDAHULUAN}

Perairan Sidodadi dan Pulau Tegal merupakan perairan yang dimanfaatkan oleh masyarakat untuk kegiatan perikanan, dalam hal ini sebagai sentral Keramba Jaring Apung (KJA). Sebagai sentral budidaya laut (marine culture) sudah tentu kondisi perairan harus mendukung atau harus dijaga untuk mendukung kegiatan tersebut. Tingginya permintaan akan produk perikanan menyebabkan masyarakat melakukan berbagai cara untuk memenuhi kebutuhan pasar tersebut, tidak terkecuali penangkapan ikan dengan cara-cara yang tidak ramah lingkungan. Selain itu, di perairan Sidodadi dan Pulau Tegal juga merupakan tempat wisata dengan akses masuk dari pantai ringgung.

Kelompok ikan karang merupakan taksa terbesar dari hewan-hewan vertebrata yang berasosiasi dengan terumbu karang, bahkan mendiami terumbu karang dengan keanekaragamn yang tertinggi (Adrim, 2007).

Ekosistem terumbu karang merupakan salah satu ekosistem pemasok pangan yang sangat potensial bagi manusia, karena berbagai jenis biota laut seperti ikan, algae, crusteacea dan molusca dapat ditemukan di ekosistem ini. Kehadiran berbagai jenis biota ini mengundang kegiatan eksploitasi sumberdaya secara besar.

Aktivitas penambangan karang, penangkapan ikan dengan bahan beracun dan bahan peledak penggunaan alat tangkap yang tidak selektif serta pencemaran yang terjadi di laut maupun di darat merupakan masalah utama terjadinya degradasi terumbu karang. Keberadaan dari biota-biota ini tidak terlepas dari peran terumbu karang yang mempunyai fungsi alarni sebagai lingkungan hidup, sebagai pelindung fisik bagi sistem pulaunya, sebagai sumber daya hayati dan sebagai sumber keindahan (SUKARNO et aL 1981). 
ODUM (1971) mengatakan bahwa terumbu karang juga merupakan benteng pertahanan terdepan daratan terhadap pukulan ombak.

\section{METODE PENELITIAN}

Penelitian ini dilaksanakan pada bulan April-Juni 2010 di 6 stasiun pada Perairan Sidodadi dan Pulau Tegal Propinsi Lampung. Penilaian kondisi terumubu karang menggunakan metode line intercept transect (LIT) atau metode transek garis menyinggung yaitu dengan cara membentangkan roll meter sepanjang 50 meter dengan posisi sejajar garis pantai (English et al., 1994). Data ikan karang diperoleh dengan metode pengamatan visual (Visual Census Method) dengan menggunakan transek garis yang sama untuk pengamatan data karang. Pencatatan data ikan karang dilakukan dengan menyelam di atas transek garis sepanjang 50 meter sambil mencatat seluruh spesies ikan dan kelimpahannya yang ditemukan sejauh $2,5 \mathrm{~m}$ ke kiri dan $2,5 \mathrm{~m}$ ke kanan dari garis transek garis sehingga luasan pengamatan $250 \mathrm{~m} 2$.

Pengamatan ikan karang dan terumbu karang dilakukan pada kedalaman 5 meter disemua stasiun. Peralatan yang digunakan adalah peralatan selam (SCUBA), alat tulis bawah air, buku identifikasi menurut Kuiter and Tonozaka (2001) dan meteran tali (meteran roll). Ikan-ikan yang dijumpai diamati jenisnya dan dicatat sepanjang garis transek tersebut. Untuk mengetahui persentase tutupan karang hidup dan berbagai indeks ekologi seperti: indeks keanekaragaman $(\mathrm{H})$, indeks dominansi (D), indeks keseragaman (E), Shannon-Wiener.
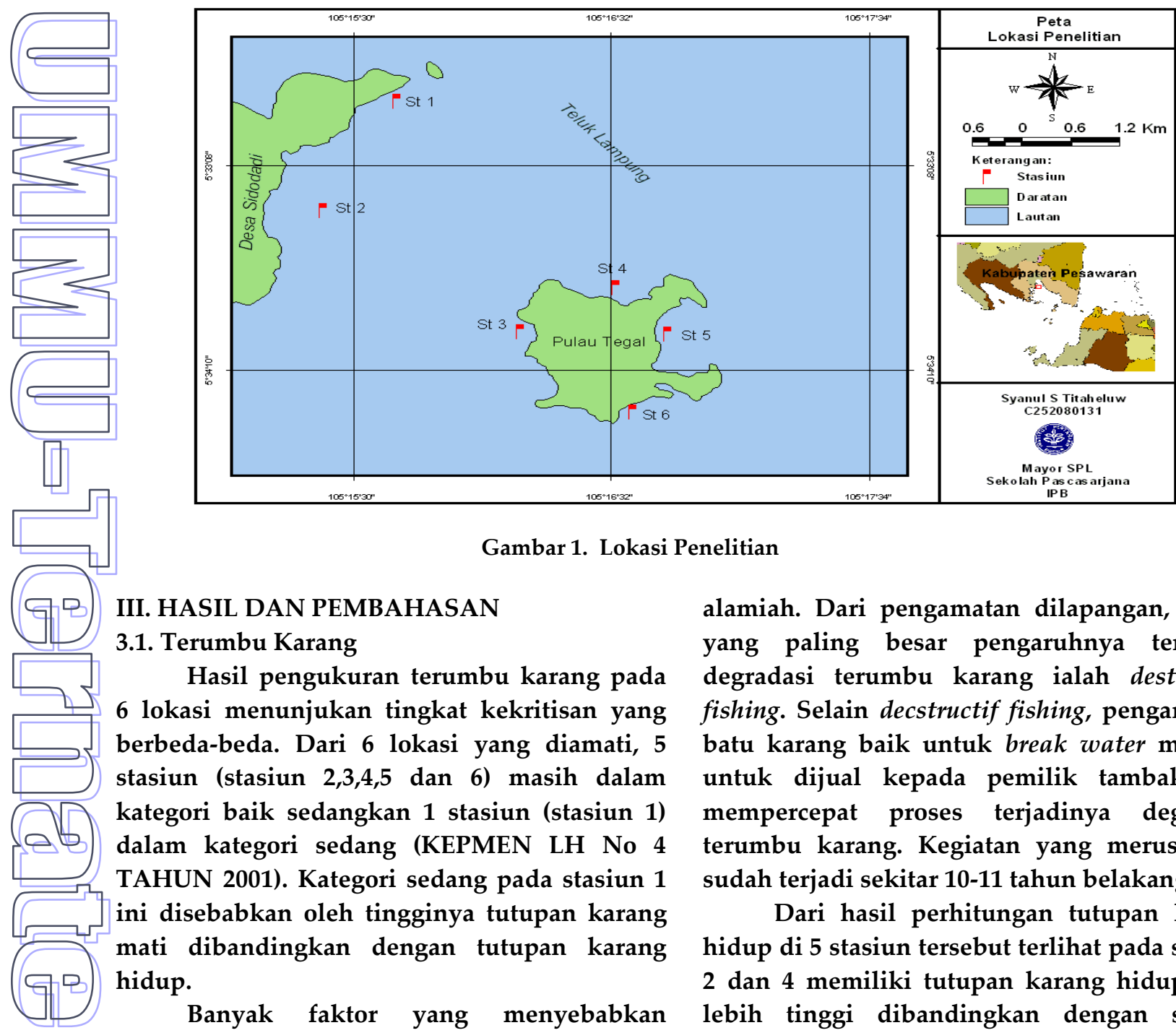

Gambar 1. Lokasi Penelitian

\section{HASIL DAN PEMBAHASAN}

3.1. Terumbu Karang

Hasil pengukuran terumbu karang pada 6 lokasi menunjukan tingkat kekritisan yang berbeda-beda. Dari 6 lokasi yang diamati, 5 stasiun (stasiun 2,3,4,5 dan 6) masih dalam kategori baik sedangkan 1 stasiun (stasiun 1) dalam kategori sedang (KEPMEN LH No 4 TAHUN 2001). Kategori sedang pada stasiun 1 ini disebabkan oleh tingginya tutupan karang mati dibandingkan dengan tutupan karang hidup.

Banyak faktor yang menyebabkan degradasi terumbu karang, diantaranya; antropogenik, alam dan kematian secara alamiah. Dari pengamatan dilapangan, faktor yang paling besar pengaruhnya terhadap degradasi terumbu karang ialah destructive fishing. Selain decstructif fishing, pengambilan batu karang baik untuk break water maupun untuk dijual kepada pemilik tambak ikut mempercepat proses terjadinya degradasi terumbu karang. Kegiatan yang merusak ini sudah terjadi sekitar 10-11 tahun belakangan.

Dari hasil perhitungan tutupan karang hidup di 5 stasiun tersebut terlihat pada stasiun 2 dan 4 memiliki tutupan karang hidup yang lebih tinggi dibandingkan dengan stasiun lainnya. Tingginya tutupan karang hidup di kedua stasiun tersebut dikarenakan adanya 
pemanfaatan yang dilakukan oleh masyarakat sekitar sebagai lokasi keramba jarring apung (KJA).

Dalam pemanfaatan potensi terumbu karang tersebut, secara tidak langsung masyarakat juga menciptakan suatu bentuk "pengawasan" yang di lakukan oleh pekerja keramba jaring apung (KJA) yang ada di lokasi penelitian. Hal ini sangat membantu ekosistem terumbu karang dari ancaman destructive fishing serta pengambilan batu karang oleh masyarakat luar dan masyarakat sekitar sebagai break water maupun untuk dijual.
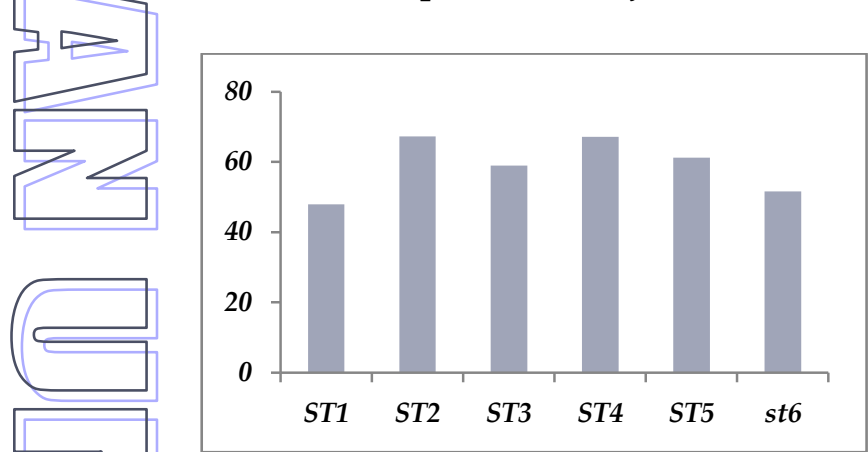

Gambar 2. Persentase Tutupan Karang Hidup

Persentase tutupan karang hidup pada stasiun 3 dan 6 lebih baik dibandingkan dengan stasiun 1, namun kegiatan dustruktif fishing yang masih terjadi pada 2 lokasi tersebut sangat mempercepat penurunan tutupan karang. Hasil pengamatan dilapangan, kedua stasiun ini sering dijadikan lokasi menangkap ikan dengan menggunakan bom atau merupakan lokasi baru untuk kegiatan destructif fishing tersebut.

Khususnya di stasiun 6 selain destructif fishing, juga merupakan tempat pengambilan batu karang untuk berbagai kebutuhan masyakat seperti break Water maupun untuk dijual dan dilakukan secara terang-terangan tanpa adanya maupun pelarangan oleh pihak yang berwajib.

\subsection{Indeks mortalitas}

Tingginya tingkat mortalitas pada stasiun 1 (Gambar 3) dikarenakan lokasi tersebut tidak adanya pengawasan atau bentuk pemanfaatan oleh masyarakat sekitar, sehingga dengan mudah kegiatan-kegiatan perikanan yang merusak berlangsung. Pada stasiun 5 sering dijadikan sebagai persinggahan kapal-kapal nelayan atau sebagai lokasi berlindung dari hempasan gelombang. Buangan jangkar dari kapal-kapal nelayan saat berlindung tersebut menyebabkan karang menjadi patah dan stasiun 6 merupakan lokasi pengambilan batu karang untuk breakwater.

Berbeda dengan stasiun 2 dan 4 yang digunakan sebagai lokasi Keramba Jaring Apung (KJA), maka kegiatan-kegiatan yang merusak tersebut dapat ditekan dengan pengawasan secara tidak langsung dari para pekerja dan pemilik keramba yang beroperasi. Lokasi-lokasi yang tidak ada pengawasannya (stasiun 1, 5 dan 6) lebih tinggi peluang terjadinya kegiatan-kegiatan perikanan yang merusak dibandingkan dengan yang ada pengawasan.

Konsekuensi dari tidak adanya pengawasan tersebut akan menyebabkan proses degradasi terumbu karang makin cepat terjadi. Tingginya tingkat degradasi tersebut secara langsung akan berpengaruh pada hilangnya Zooxantella karang dan secara langsung akan berdampak pada kelangsungan hidup ikan karang yang berasosiasi dengan terumbu karang tersebut, terutama ikan indokator (C. Trifascialis). Titaheluw (2015) mengatakan perubahan persentase tutupan karang hidup akan mempengaruhi kelimpahan dan cendrung di dominasi oleh salah satu spesies karena keterkaitannya dengan makanan.

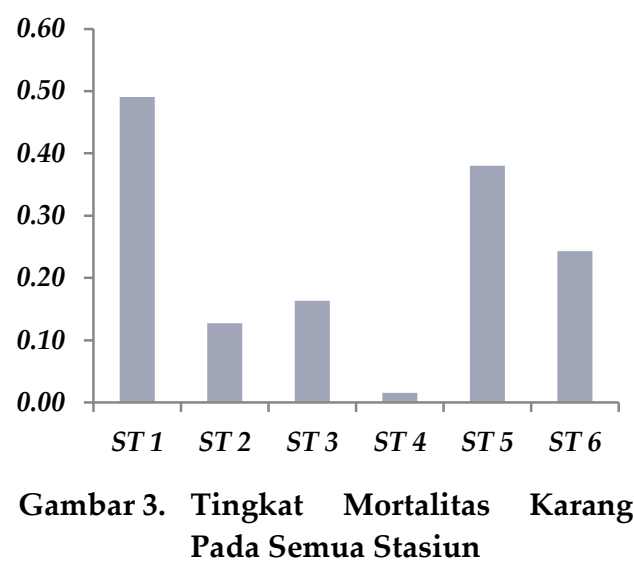

\subsection{Ikan Karang}

Jumlah total ikan yang tersensus selama penelitian sebanyak 684 ekor yang mewakili 14 suku (tabel 1). Ikan-ikan tersebut dibedakan dalam 3 kelompok mengikuti cara DARTNALL \& JONES (1986), yakni kelompok ikan target, 
ikan indikator, dan kelompok lain-lain (major group). Ikan target sebanyak 135 ekor yang mewakili 5 suku, ikan indikator sebanyak 115 yang mewakili 2 suku dan ikan mayor major grup sebanyak 434 jenis yang mewakili 7 suku.
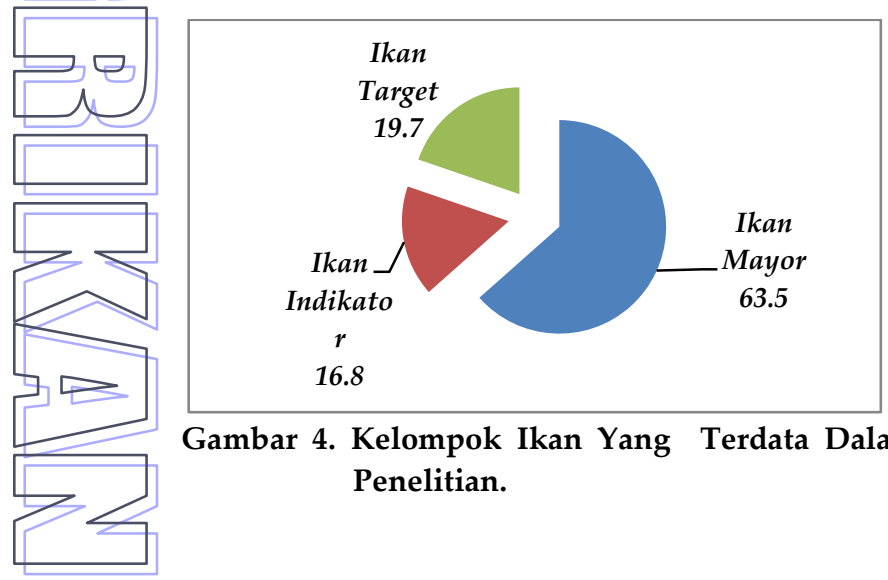

Gambar 4. Kelompok Ikan Yang Terdata Dalam Penelitian.
Pada Tabel 1 menunjukan stasiun 1 mempunyai kelimpahan ikan yang paling rendah bila dibandingkan dengan 5 stasiun lainnya. Tingginya tekanan antropogenik terhadap terumbu karang pada stasiun 1 bekorelasi positif dengan kelompahan ikan yang tersensus dalam penelitian.

Tekanan tersebut menyebabkan persedian makanan menjadi menjadi berkurang, faktor inilah yang menyebabkan kelimpahan ikan menjadi rendah. Hal yang berbeda terjadi pada stasiun 2 dan 4 yang mempunyai kelimpahan yang lebih tinggi. Tingginya tutupan karang hidup pada dua lokasi tersebut menyebabkan ketersediaan makanan bagi ikan karang menjadi jaminan untuk datang dan menatap bagi ikan-ikan Mayor, Indokator maupun Target.

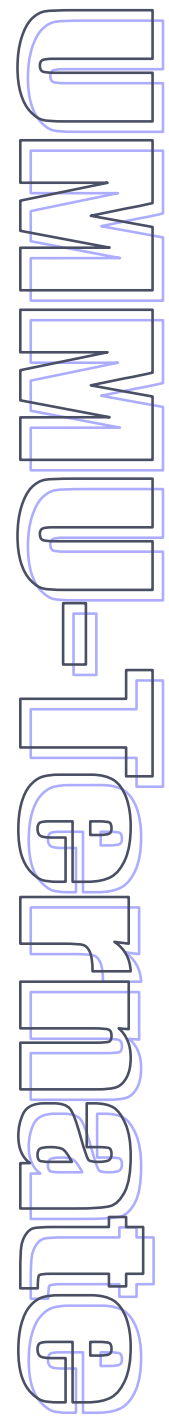

Table 1. Jumlah Ikan Yang Tersensus Di 6 Lokasi Penelitian

\begin{tabular}{|c|c|c|c|c|c|c|c|c|}
\hline \multirow{2}{*}{ Peranan } & \multirow{2}{*}{ Famili } & \multirow{2}{*}{ Spesies } & \multicolumn{6}{|c|}{ Kelimpahan } \\
\hline & & & ST1 & ST2 & ST3 & ST4 & ST5 & ST6 \\
\hline \multirow[t]{31}{*}{ Mayor } & Pomacentridae & A. Bagiliensis & 4 & 6 & 5 & 3 & 4 & 6 \\
\hline & & A. Lorenzi & 2 & 4 & 2 & 6 & 0 & 0 \\
\hline & & A. Vaigiensis & 1 & 3 & 2 & 2 & 4 & 4 \\
\hline & & Chromis analis & 2 & 1 & 0 & 3 & 0 & 5 \\
\hline & & D. trimaculatus & 0 & 8 & 3 & 10 & 0 & 3 \\
\hline & & C. atripectoralis & 2 & 0 & 6 & 7 & 4 & 8 \\
\hline & & Pomacentrus bankanensis & 4 & 5 & 7 & 6 & 5 & 3 \\
\hline & & chrysiptera cyanea & 0 & 3 & 6 & 0 & 3 & 0 \\
\hline & & Pomacentrus mullocencis & 4 & 7 & 5 & 9 & 5 & 8 \\
\hline & & Dishistodus melanotus & 4 & 5 & 6 & 6 & 5 & 0 \\
\hline & Pomachantidae & Pygoplites diacanthus & 0 & 2 & 0 & 5 & 2 & 1 \\
\hline & & Pomacanthus annularis & 3 & 1 & 0 & 0 & 0 & 0 \\
\hline & & Centropyge bicolor & 0 & 0 & 0 & 0 & 2 & 4 \\
\hline & Caesio & C. lunaris & 2 & 5 & 9 & 3 & 0 & 1 \\
\hline & Scaridae & Chlorurus bowersi & 0 & 4 & 0 & 1 & 4 & 0 \\
\hline & & C. sordidus & 1 & 5 & 0 & 2 & 7 & 0 \\
\hline & & C.troschelii & 4 & 2 & 0 & 4 & 1 & 2 \\
\hline & Labridae & Chellinus fasciatus & 1 & 5 & 0 & 1 & 0 & 1 \\
\hline & & Coris gaimard & 2 & 1 & 0 & 3 & 1 & 1 \\
\hline & & Diprotacanthus xanthurus & 3 & 5 & 0 & 3 & 2 & 1 \\
\hline & & Gomphosus varius & 5 & 6 & 0 & 4 & 1 & 2 \\
\hline & & Halichoeres chrysus & 3 & 4 & 1 & 5 & 5 & 2 \\
\hline & & Labroides dimidiatus & 2 & 0 & 4 & 5 & 0 & 0 \\
\hline & & Thalassoma lunare & 2 & 0 & 5 & 0 & 0 & 4 \\
\hline & & T. Trilobatum & 0 & 2 & 0 & 0 & 3 & 2 \\
\hline & Apogonidae & Apogon chyrsopomus & 0 & 0 & 0 & 3 & 0 & 0 \\
\hline & & A. Aureus & 0 & 0 & 0 & 0 & 5 & 0 \\
\hline & & A. Trimaculatus & 3 & 0 & 0 & 3 & 0 & 0 \\
\hline & & A. Novemfasciatsu & 0 & 2 & 0 & 2 & 0 & 0 \\
\hline & & A. Compressus & 0 & 0 & 0 & 6 & 1 & 0 \\
\hline & Zanclidae & Zanclus cornutus & 0 & 2 & 0 & 0 & 4 & 3 \\
\hline Indikator & $\begin{array}{l}\text { Famili } \\
\text { Chaetodontidae }\end{array}$ & Octofasciatus & 11 & 6 & 6 & 8 & 6 & 9 \\
\hline
\end{tabular}




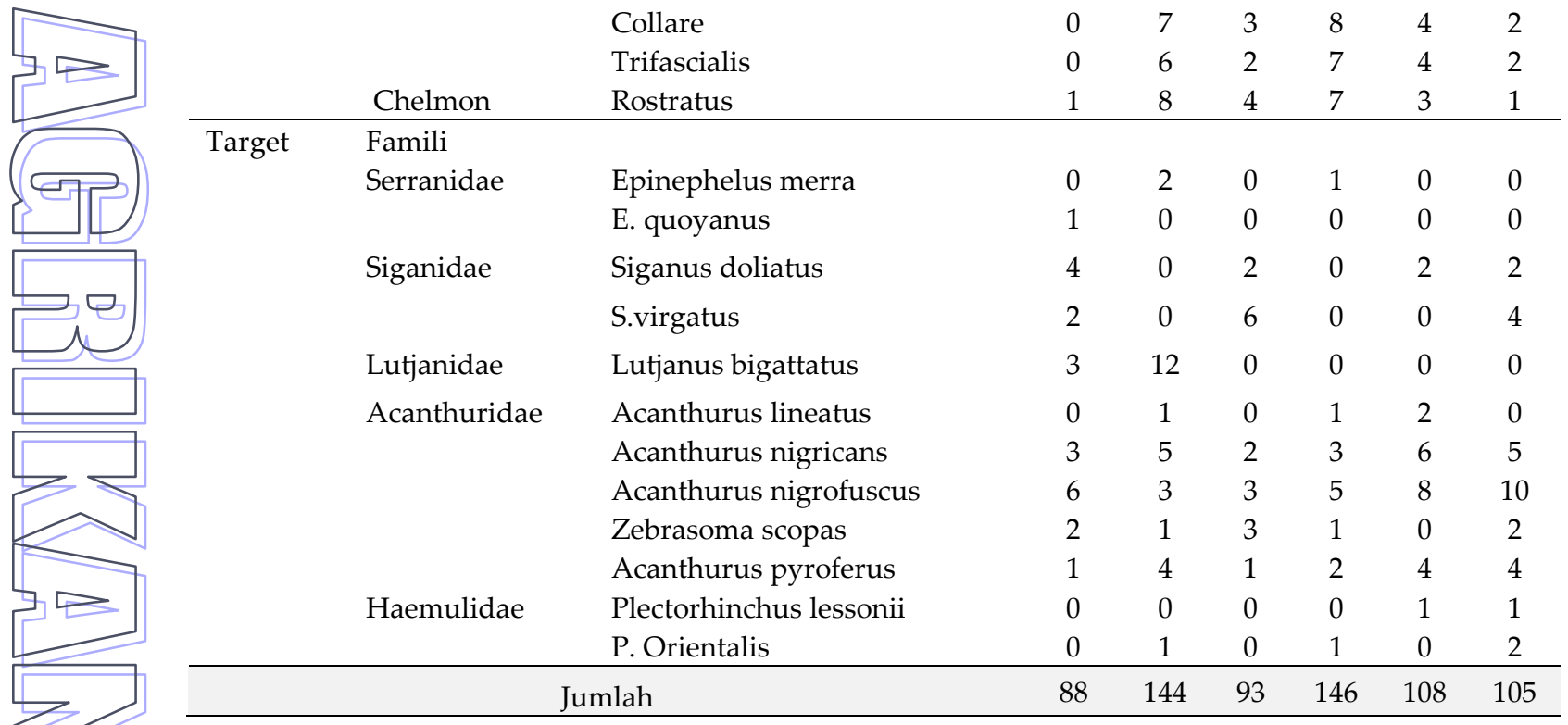

Selain itu, kedua lokasi tersebut dimanfaatkan oleh masyarakat sebagai tempat budidaya keramba jaring apung. Dengan pemanfaatan potensi tersebut, masyarakat secara tidak langsung juga telah melakukan pengawasan terumbu karang.

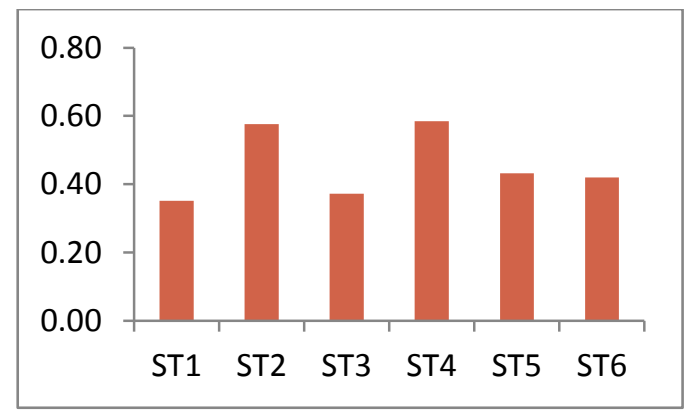

Gambar 5. Kelimpahan Ikan

Jumlah ikan target yang tersensus di lokasi penelitian juga mempunyai persentase yang sangat kecil, hal ini di duga karena tingginya intensitas penangkapan yang menggunakan alat yang tidak ramah lingkungan tersebut sehingga merusak lokasi feedeng ground dari ikan tersebut.

Bila dibandingkan kondisi ikan karang yang tersensus di perairan Sidodadi dan Pulau Tegal dengan beberapa perairan di Indonesia, maka kondisi ekologi perairan tersebut sudah termaksud dalam tahap yang "memprihatinkan". Hal ini dikarenakan tingginya aktifitas yang merusak, sehingga menyebabkan kondisi lingkungan dari ikanikan karang menjadi rusak.

\subsection{Keanekaragaman}

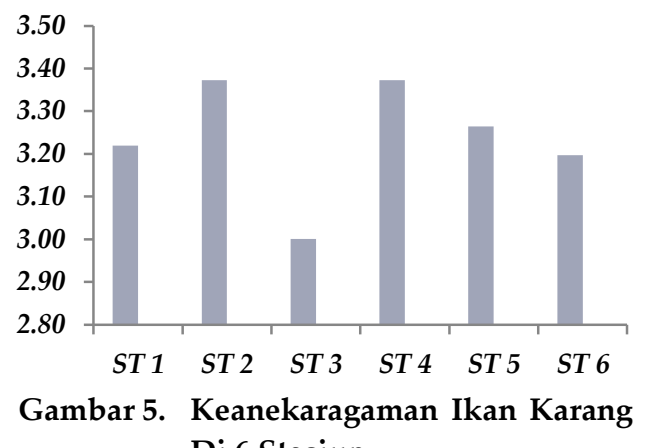

Di 6 Stasiun

Keanekaragaman ikan yang di temukan cukup beragam, dari 3,00-3,37. Dari gambar 5 terlihat keanekaragman tertinggi terdapat pada stasiun 2 dan 4, dimana pada kedua stasiun tersebut memiliki nilai indeks sebesar 3,37. Berdasarkan kategori Shannon-Wiener, keanekaragaman di enam stasiun tergolong dalam kategori renda.

Hal mengindikasikan kondisi ekosistem di seluruh stasiun penelitian mengalami tekanan atau dalam kondisi menurun. Jika dilihat nilai indeks berdasarkan stasiun, hanya stasiun 2 dan 4 saja yang masih dalam ketegori sedang dan stasiun 3 yang mempunyai tekanan paling besar dengan nilai $\left(H^{\prime} 3,00\right)$.

Bila dilihat dari 3 kelompok besar (ikan target, indikator dan mayor) ikan karang, terlihat spesies-spesies yang mendominasi di tiap stasiun. Kelompok ikan target di dominasi oleh Acanhirudae. Spesies ini tergolong kedalam kelompok ikan herbivora dan harga 
jual dipasar tidak terlalu tinggi seperti ikan target lainnya.

Kelompok indikator di dominasi oleh Chaetodon, sebagai genus yang paling banyak jumlah jenisnya, juga merupakan kelompok Obligate coralivor. Dengan demikian, dominansi dari genus tersebut dalam kategori yang wajar. Namun jika di lihat dari spesies, kondisi ekosistem cukup mengalami tekanan dan sangat memprihatinkan. Dari kelompok ikan mayor, di dominasi oleh Pomacentridae, kelompok ikan ini mempunyai sifat teritorial dan mobilitas yang sempit.

Tabel 2. Kondisi Ikan Karang Di Beberapa Perairan Indonesia

\begin{tabular}{lcl}
\hline Lokasi & Jumlah Genera & Referensi \\
\hline Belitung & 18 & Adrim M \& Yahmantoro, 1991 \\
Biak & 43 & Hukom F D \& Syahailatua A, 1995 \\
Kepualauan Lease & 32 & La Tanda \& Hukom F D, 1994 \\
Pulau Enggano & 22 & Adrim M, 2007 \\
Sidodadi \& Pulau Tegal & 14 & Studi Sekarang, 2010 \\
\hline
\end{tabular}

Menurut LIESKE \& MYERS (1997), Banyak jenis ikan karang pemakan karang memperlihatkan prilaku teritorial dan mobilitas yang sempit di sekitar terumbu karang, di mana banyak diantaranya tidak pergi jauh dari sumber makanan dan tempat perlindungannya.

Tingginya keanekaragaman pada stasiun 2 dan 4 (gambar 4) merupakan implikasi dari adanya "pengawasan" yang dilakukan melalui pemanfaatan potensi sumberdaya ekosistem terumbu karang yang di lakukan oleh para pekerja keramba jaring apung (KJA). Tingginya persentase tutupan karang hidup di kedua stasiun tersebut memberikan dampak positif bagi ikan-ikan karang yang merupakan habitatnya sehingga keaneragaman pada stasiun ini menjadi tinggi dari stasiun lainnya.

Menurut MASUDA et al. (1984), ANONIM (1999a, 1999b, 2001a, dan 2001b) sebagian besar suku (family) ikan dari bangsa (ordo) Perciformes hidup menetap di terumbu karang. Ketersediaan makanan yang masih baik bagi ikan-ikan karang, menyebabkan komunitas ikan tidak punah dan berruaya ke tempat lain untuk mencari makan dan tempat berlindung yang baru.

\subsection{Keseragaman}

Kondisi suatu ekosistem terumbu karang sangat mempengaruhi keseragaman setiap komunitas ikan yang mendiami lokasi tesebut. Kondisi ini juga berlaku pada komunitas ikan yang mendiami pulau Sidodi dan Pulau Tegal.

Bila di lihat pada gambar 6 , keseragaman ikan pada masing-masing stasiun menunjukan nilai yang berbeda. Nilai paling tertingi terdapat pada stasiun $3(0,32)$ sedangkan yang terendah terdapat pada stasiun 2 dan $4(0,28)$.

Berdasarkan nilai standar shannonwiener, indeks keseragaman berkisar antara 01, jika $0<\mathrm{E} \leq 0,4$ keseragaman kecil (komunitas tertekan), $\quad 0,4<\mathrm{E} \leq 0,6 \quad$ keseragaman sedang (komunitas labil) dan $0,6<\mathrm{E} \leq 1$ keseragaman tinggi (komunitas stabil).

Dengan menggunakan standar indeks tersebut, penelitian ini menemukan kondisi komunitas ikan karang pada perairan Sidodadi dan Pulau Tegal dalam kondisi tertekan yang diakibatkan oleh kegiatan antropogenik oleh masyarakat luar maupun sekitarnya dalam memanfaatkan potensi terumbu karang. Ikanikan yang ditemukan pada lokasi penelitian merupakan jenis ikan yang mempunyai teritori dan ruaya sempit.

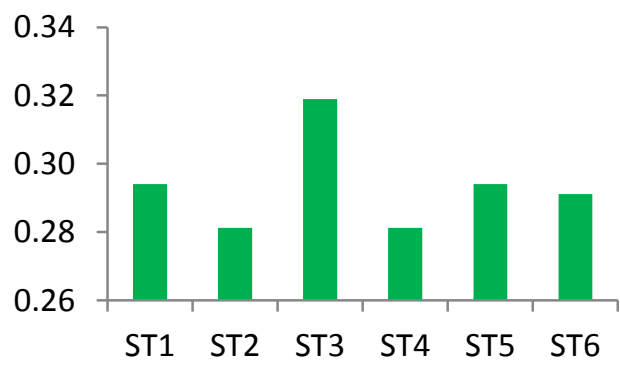

Gambar 6. Keseragaman Ikan Karang

\subsection{Dominansi}

Dominansinya suatu spesies dalam satu komunitas mengindikasikan telah terjadi atau adanya tekanan yang menyebabkan keberadaan spesies lain berkurang atau hilang, hal yang sama juga terjadi pada kondisi 
terumbu karang serta komunitas ikan karang di perairan Sidodadi dan Pulau Tegal.

Dominansi tertinggi terdapat pada stasiun 3 oleh kelompok mayor sebanyak 13 spesies $(57 \%)$, indikator sebanyak 4 spesies $(17 \%)$ dan target sebanyak 6 spesies $(26 \%)$.

Besarnya kelimpahan jenis ikan kelompok mayor (major family) dikarenakan adanya variasi habitat seperti berbatu, pasir, karang dan campuran batu pasir yang cocok bagi tempat hidup jenis-jenis ikan tertentu. Hal ini menunjukkan bahwa jenis ikan yang berkelompok tidak akan bermigrasi ketempat yang lebih jauh dikarenakan habitatnya yang sudah sesuai untuk perkembangan dan pertumbuhannya (Panggabean, 2012).

Menurut LIESKE \& MYERS (1997), Banyak jenis ikan karang pemakan karang memperlihatkan prilaku teritorial dan mobilitas yang sempit di sekitar terumbu karang, di mana banyak diantaranya tidak pergi jauh dari sumber makanan dan tempat perlindungannya.

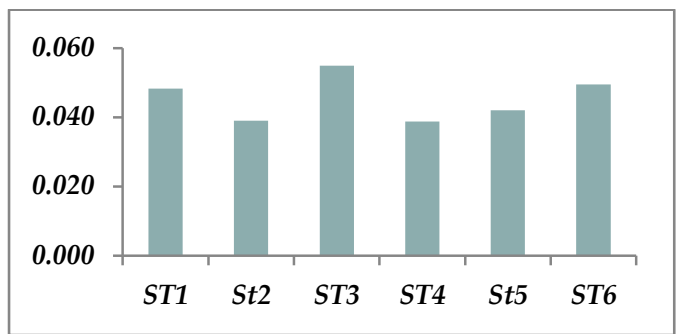

Gambar 7. dominansi ikan di 6 stasiun

IV. Kesimpulan

1. Secara umum kondisi terumbu karang di perairan Sidodadi dan Pulau Tegal dalam kategori baik dengan rata-rata persentase tutupan karang hidup sebesar 59,02\%, hal ini juga didukung oleh pemanfaatan potensi terumbu karang sebagai Keramba Jaring Apung oleh masyarakat.

2. Tingginya aktifitas antropogenik akan mempercepat proses degradasi terumbu karang dan komunitas ikan karang.

3. Struktur Komunitas ikan karang di Perairan Sidodadi dan Pulau Tegal dalam kategori rendah, yang merupakan implikasi dari kegiatan antropogenik yang terjadi di perairan tersebut.

\section{DAFTAR PUSTAKA}

Adrim, M., 2007. Komunitas Ikan Karang di Perairan Pulau-Pulau Marabatua dan Sekitarnya, Kalimantan Selatan. Torani, Vol. 17 (2) Edisi Juni 2007: 121-132.

Adrim M, Hutomo M, Suharti S R. 1991. Chaetodontid fish community Structure and Its Relation to Reef Degradation at the Seribu Islans Reefs, Indonesia. Proceedings of the Regional Symposium on Living Resources in Coastal Areas. Phillipine.

FAO species identification guide for fishery purposes. 1999a . The living marine resources of the Western Central Pacific. Volume 3. In : CARPENTER, K. E. \& V. H.NIEM (eds.). Batoid fishes, chimaeras and bony fishes part 1 (Elopidae to Linophrynidae). Rome: 1540-2068.

FAO species identification guide for fishery purposes. 1999b. The living marine resources of the Western Central Pacific. Volume 4. In : CARPENTER, K. E. \& V. H.NIEM (eds.). Bony fishes part 2 (Mugilidae to Carangidae). FAO, Rome: 2069-2790.

FAO species identification guide for fishery purposes. 2001a. The living marine resources of the Western Central Pacific. Volume 5. In : CARPENTER, K. E. \& V. H.NIEM (eds.). Bony fishes part 3 (Menidae to Pomacentridae). FAO, Rome: 2791-3380.

FAO species identification guide for fishery purposes. 2001b. The living marine resources of the Western Central Pacific. Volume 6. In : CARPENTER, K. E. \& V. H.NIEM (eds.). Bony fishes part 4 (Labridae to Latimeriidae, estuarine crocodiles, sea turtles, sea snakes and marine mammals). FAO, Rome: 3381- 4218. 